\title{
OPEN
}

Published online: 24 December 2019

\section{Author Correction: Dentate granule and mossy cells exhibit distinct spatiotemporal responses to local change in a one-dimensional landscape of visual-tactile cues}

\section{Dajung Jung, Soyoun Kim, Anvar Sariev, Farnaz Sharif, Daesoo Kim \& Sebastien Royer}

Correction to: Scientific Reports https://doi.org/10.1038/s41598-019-45983-6, published online 02 July 2019

In the original version of this Article, Affiliations 1, 2 and 3 were not listed in the correct order. The correct affiliations are listed below:

Affiliation 1:

Department of biological sciences, Korea Advanced Institute of Science and Technology, Daejeon, 34141, Republic of Korea.

Affiliation 2:

Center for Functional Connectomics, Korea Institute of Science and Technology, Seoul, 02792, Republic of Korea.

Affiliation 3:

Division of Bio-Medical Science and Technology, KIST School, Korea University of Science and Technology, Seoul, 02792, Republic of Korea.

This error has now been corrected in the PDF and HTML versions of the Article.

(c) (1) Open Access This article is licensed under a Creative Commons Attribution 4.0 International License, which permits use, sharing, adaptation, distribution and reproduction in any medium or format, as long as you give appropriate credit to the original author(s) and the source, provide a link to the Creative Commons license, and indicate if changes were made. The images or other third party material in this article are included in the article's Creative Commons license, unless indicated otherwise in a credit line to the material. If material is not included in the article's Creative Commons license and your intended use is not permitted by statutory regulation or exceeds the permitted use, you will need to obtain permission directly from the copyright holder. To view a copy of this license, visit http://creativecommons.org/licenses/by/4.0/.

(c) The Author(s) 2019 